STUDIA PRAWNO-EKONOMICZNE, t. CIV, 2017

PL ISSN 0081-6841; e-ISSN 2450-8179 $\quad$ s. 201-221

DOI: 10.26485/SPE/2017/104/11

\title{
UNVEILING THE TIME EFFECT OF A SHOCK ON ELECTRICITY CONSUMPTION: EVIDENCE FROM POST-TRANSITION EU COUNTRIES ${ }^{1}$
}

(Summary)

This paper explores the time-series properties of the relative per capita electricity consumption series disaggregated by consumer sectors for the presence of a unit root for eleven post-transition EU countries. To that end, the panel unit root tests without and with structural break(s) were used covering the period 2002-2013.

The results of the former indicate that electricity consumption is the unit root process for each sector, indicating that any shock thereto is likely to be permanent. The results of the latter support the non-stationary null for the majority of the countries and sectors under investigation, and also point out that each country was exposed to at least one significant shock affecting some of the electricity consumption variables. Thereby, the shocks will probably have permanent effects on them, and their electricity consumption will be path-dependent. Consequently, there is little evidence of convergence of post-transition EU countries to the single electricity market.

Keywords: stationarity; panel unit root tests; shock; post-transition EU countries

JEL Classification: C23, P28, Q49

\section{Introduction}

The European Union (EU) wants to establish a resilient Energy Union with an ambitious climate policy and an integrated internal energy market, to design a common European energy policy, and to have a secure, sustainable and

* Full Professor, Josip Juraj Strossmayer University of Osijek, Faculty of Economics in Osijek, Croatia; e-mail: borozan@efos.hr

1 Acknowledgement: This paper was supported by the Croatian Science Foundation under Grant number IP-2013-11-2203. 
competitive energy supply. These objectives are explicitly written in many EU energy strategic documents. However, a significant degree of energy dependence on particular fuels, energy suppliers and routes has rendered EU vulnerable to energy shocks and contributed to deviation from the energy targets ${ }^{2}$.

In the last decade, EU was exposed to many different shocks having consequences on electricity consumption. Unveiling their character, which may be temporary or permanent, should become an important research subject not only for researchers but also for energy policy makers and practitioners. Namely, as suggested by many studies ${ }^{3}$, if a shock to electricity consumption has a temporary effect, electricity consumption will return to its trend path and the shock will not demand changes in energy and environment policy. Moreover, the past development of electricity consumption can be used to forecast electricity consumption and energy demand, what could have favorable macroeconomic and ecological consequences. On the other hand, if a shock has a permanent effect, it will generate significant impacts not only on energy consumption, but it may also be transmitted to other macroeconomic variables such as income, employment, wages and the like, as stressed by Hendry and Juselius ${ }^{4}$. In that case, electricity consumption will not return to its equilibrium level, and its past behavior would not be useful in forecasting future trends in electricity consumption ${ }^{5}$. Moreover, finding evidence of a unit root provides evidence supporting the unit root or no-convergence hypothesis, while rejecting a unit root of the stationarity or convergence hypothesis.

Recently, the assessment of the stationarity of electricity consumption by using different panel unit root tests has attracted the attention of researchers and

2 D. Buchan, Refuelling Europe: A roadmap for completing the Single energy market, Wilfried Martens Centre for European Studies, Brussels 2014.

3 See, for example: P.K. Narayan, R. Smyth, Are shocks to energy consumption permanent or temporary? Evidence from 182 countries, Energy Policy 2007/35: 333-341; Y.C. Hsu, C.C. Lee, C.C. Lee, Revisited: Are shocks to energy consumption permanent or temporary? New evidence from a panel SURADF approach, Energy Economics 2008/30: 2314-2330; V. Mishra, S. Sharma, R. Smyth, Are fluctuations in energy consumption per capita transitory? Evidence from a panel of Pacific Island countries, Energy Policy 2009/37 (6): 2318-2326; H. Kum, Are fluctuations in energy consumption transitory or permanent? Evidence from a panel of East Asia \& Pacific countries, International Journal of Energy Economics and Policy 2012/2 (3): 92-96.

4 D.F. Hendry, K. Juselius, Explaining cointegration analysis: part 1, Energy Journal 2000/21: $1-42$.

5 M. Shahbaz, A.K. Tiwari, I. Ozturk, A. Farooq, Are fluctuations in electricity consumption per capita transitory? Evidence from developed and developing economies, Renewable and Sustainable Energy Reviews 2013/28: 551-554; R. Smyth, Are fluctuations in energy variables permanent or transitory? A survey of the literature on the integration properties of energy consumption and production, Applied Energy 2013/104: 371-378. 
consequently many studies emerged in this field ${ }^{6}$. Namely, a temporary effect occurs if electricity consumption is a stationary process, whereas a permanent effect occurs if electricity consumption is a non-stationary (unit root) process. However, the majority of the studies considered the issue of the stationarity of electricity consumption in the context of developed or Asia and Pacific region countries. Their empirical results are mixed; some of them indicate electricity stationarity, while others point out electricity non-stationarity. Smith ${ }^{7}$ illuminates a lack of studies for Europe. However, little or no attention has been devoted to this issue regarding post-transition EU countries.

By using different panel unit root tests, this paper aims to test the stationary properties of per capita electricity consumption disaggregated by consumer sectors for eleven post-transition EU countries covering the period 2002-2013. Energy sectors of post-transition EU countries certainly have some common characteristics; for the last 25 years they have been in the process of continuous changes corresponding to social, political and economic transition. Before the 1990 s, i.e., in the period of communism/socialism, their institutional energy infrastructure (such as regulatory agencies or electricity markets) was undeveloped and electricity competition did not exist, physical infrastructure was outdated with a chronic shortage of capacity since most of investment was conducted in the 1950s and the 1960s. Consequently, their energy sectors were inefficient, unreliable and as Ivanovic et al. ${ }^{8}$ stated, their energy policy significantly irrational. From the 2000s, they have engaged in energy reforms following the EU reform model $^{9}$. However, these similarities do not necessarily imply that the timeseries properties of electricity consumption, and hence a degree of electricity consumption convergence or divergence, will be the same for all of them.

The remainder of this paper is organized as follows: Section 2 describes the data and methodology, whereas Sections 3 and 4 provide empirical results and conclusions, respectively.

${ }_{6}$ For a summary review, see: Y.C. Hsu, C.C. Lee, C.C. Lee, Revisited..., pp. 2314-2330; A. Aslan, H. Kum, The stationarity of energy consumption for Turkish disaggregate data by employing linear and nonlinear unit root tests, Energy 2011/36: 4256-4258; H. Kum, op. cit., pp. 92-96; R. Smyth, op. cit., pp. 371-378; M. Shahbaz, A.K. Tiwari, I. Ozturk, A. Farooq, Are fluctuations..., pp. 551-554.

R. Smyth, op. cit., pp. 371-378.

8 M. Ivanovic, D. Blazevic, H. Glavas, The structure of electricity consumption and its utilization efficiency in the European transition countries, International Journal of Electrical and Computer Engineering Systems 2010/1 (2): 19-34.

9 See M. Pollitt, Evaluating the evidence on electricity reform: Lessons for the South East Europe (SEE) market, Utilities Policy 2009/17 (1): 13-23, and the EBRD's annual assessment of the progress of reforms in the electricity sector. 


\section{Literature review}

It is only recently that an empirical investigation of the existence of a unit root in per capita energy consumption or the energy convergence has become a field of interest to economists ${ }^{10}$. As mentioned in the Introduction, the results of these investigations, mostly concentrated on developed or Asia and Pacific region countries, are mixed ${ }^{11}$.

However, the studies on the time-series properties of the electricity consumption series or the electricity convergence hypothesis in general are limited at the EU level.

Markandya et al. ${ }^{12}$ analyze the relationship between energy intensity in 12 Eastern European countries and 12 EU members for the period 1992-2002. They find some evidence of convergence, and also that the countries with the fastest convergence rates are the Czech Republic, Bulgaria, Croatia and Turkey. Using $\beta$ - and $\sigma$-convergence, Ortiz et al. ${ }^{13}$ test the existence of convergence in energy intensity across Europe for the period 1990-2004 and find a sensible catch up of less performing countries, particularly in the agricultural and the industrial sectors. Le Pen and Sevi ${ }^{14}$ also test for convergence of energy intensity for the group of 97 countries in the period 1971-2003, but applying different unit root tests and a stationarity test. Their results reject the global convergence hypothesis although for European subgroups they find that non-convergence is less strongly rejected. Hajko ${ }^{15}$ examines energy intensity convergence using $\beta$ - and $\sigma$-convergence in EU-27 Member States in the period 1990-2009, too. He concludes that there is evidence of energy intensity convergence in the group of new Member States and in total EU27, while there is no evidence thereof in the old Member States.

10 P.K. Narayan, R. Smyth, Are shocks to energy..., pp. 333-341; P.K. Narayan, S. Narayan, S. Popp, Energy consumption at the state level: the unit root null hypothesis from Australia, Applied Energy 2010/87: 1953-1962; A. Aslan, Does natural gas consumption follow a nonlinear path over time? Evidence from 50 states, Renewable and Sustainable Energy Reviews 2011/15: 4466-4469.

11 For a summary review, see: Y.C. Hsu, C.C. Lee, C.C. Lee, Revisited..., pp. 2314-2330; A. Aslan, Does natural gas..., pp. 4466-4469; H. Kum, op. cit., pp. 92-96; R. Smyth, op. cit., pp. 371-378; M. Shahbaz, A.K. Tiwari, I. Ozturk, A. Farooq, op. cit., pp. 551-554.

12 A. Markandya, S. Pedroso, D. Streimikiene, Energy efficiency in transition economies: Is there convergence towards the EU average?, Energy Economics 2004/28 (1): 121-145.

13 R.A. Ortiz, A. Bastianin, A. Bigano, C. Cattaneo, A. Lanza, M. Manera, A. Markandya, M. Plotegher, F. Sferra, Energy efficiency in Europe: Trends, convergence and policy effectiveness, MPRA Paper No. 15763, Munich 2009.

14 Y. Le Pen, B. Sevi, On the non-convergence of energy intensities: Evidence from a pair-wise econometric approach, Ecological Economics 2010/69 (3): 641-650.

15 V. Hajko, Changes in the energy consumption in EU-27 countries, Review of Economic Perspectives 2012/1: 3-21. 
Robinson ${ }^{16}$ analyses the extent to which wholesale electricity prices for nine European countries converged during the period 1978-2003 using $\beta$-convergence. His results support the convergence hypothesis for most of the sample countries. However, employing principal component analysis of wholesale electricity prices in 2002-2006, Zachmann ${ }^{17}$ demonstrates that there is enough evidence to reject the hypothesis of full European electricity market integration over the period 2002-2006. He claims that for several pairs of countries, only a weaker hypothesis of (bilateral) convergence is accepted based on two unit root tests. Using fractional cointegration to assess the convergence of 15 European spot markets by January 2012, Pellini ${ }^{18}$ concludes that the integration of European electricity markets still has a long way to go.

Teixeira et al. ${ }^{19}$ deem that European countries are converging to a common energy policy, even though some countries, particularly Southern European countries, seem to lag behind others.

To sum up, limited evidence indicates that the results of the tests are mixed, dependent on the energy variable analyzed and the method applied. Namely, considering a particular energy variable point of view, some of them provide evidence supporting the unit root or non-convergence hypothesis, while the other ones support the stationarity or convergence hypothesis.

\section{Data and methodology}

\subsection{Per capita electricity consumption data}

The stationarity of per capita electricity consumption series is examined for a sample composed of eleven post-transition EU countries: Bulgaria, the Czech Republic, Estonia, Croatia, Latvia, Lithuania, Hungary, Poland, Romania,

16 T. Robinson, The Convergence of Electricity Prices in Europe, Applied Economics Letters 2007/14: 473-476.

17 G. Zachman, Electricity wholesale market prices in Europe: Convergence?, Energy Economics 2008/30 (4): 1659-1671.

18 E. Pellini, Convergence across EU electricity wholesale spot markets: Still a way to go, in: Proceedings of the $12^{\text {th }}$ IAEE European Energy Conference, Venice, 1-36, 2012, https://editorialexpress.com/cgi-bin/conference/download.cgi?db_name=res_phd_2013\&paper_id=274; retrieved 20.10.2015.

19 C. Teixeira, M. Albano, A. Skou, L. Perez Duenas, F. Antonacci, R. Ferreira, K. Lotzfeldt Pedersen, S. Scalari, Convergence to the European energy policy in European countries: Case studies and comparison, Social Technologies 2014/4 (1): 7-24. 
Slovenia and Slovakia. The yearly data, obtained by Eurostat ${ }^{20}$, refer to final electricity consumption disaggregated by sectors for the period 2002-2013.

Final electricity consumption covers electricity supplied to the final consumer's door for all energy uses, except for own use by electricity producers or transmission and distribution losses. The major electricity end-use sectors are the industrial sector, household sector, service sector and transportation sector. More precisely, according to Eurostat's definition, final energy consumption in industry covers all industrial sectors with the exception of the energy sector (e.g., like power stations, oil refineries and all other installations transforming energy products into another form), while final energy consumption in transport covers mainly the consumption by railways and electrified urban transport systems. Final energy consumption in households/services covers quantities consumed by private households, small-scale industry, crafts, commerce, administrative bodies, services with the exception of transportation, agriculture and fishing. Final electricity consumption is calculated as the sum of final electricity consumption from all the above mentioned sectors, and given in $\mathrm{kWh}$. The source of population data is the International Monetary Fund's World Database.

The development of per capita total electricity consumption by post-transition EU countries and the average of the series for the period considered are illustrated by Figure 1 and Figure 2, respectively.

FIGURE 1: Development of per capita total electricity consumption by post-transition EU countries

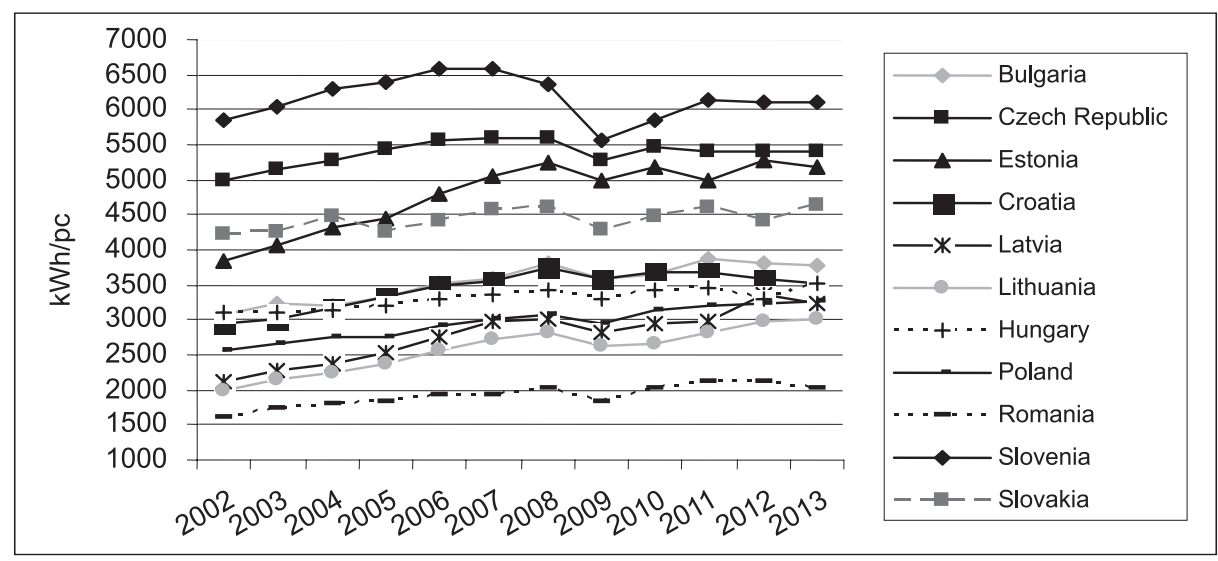

S o u r c e: Eurostat ${ }^{21}$.

20 Eurostat, Electricity and heat statistics, data from May 2015, http://ec.europa.eu/eurostat/ statistics-explained/index.php/Electricity_and_heat_statistics; retrieved 2.08.2015.

21 Ibidem. 
FIGURE 2: Average of per capita electricity consumption by sectors over the period 2002-2013

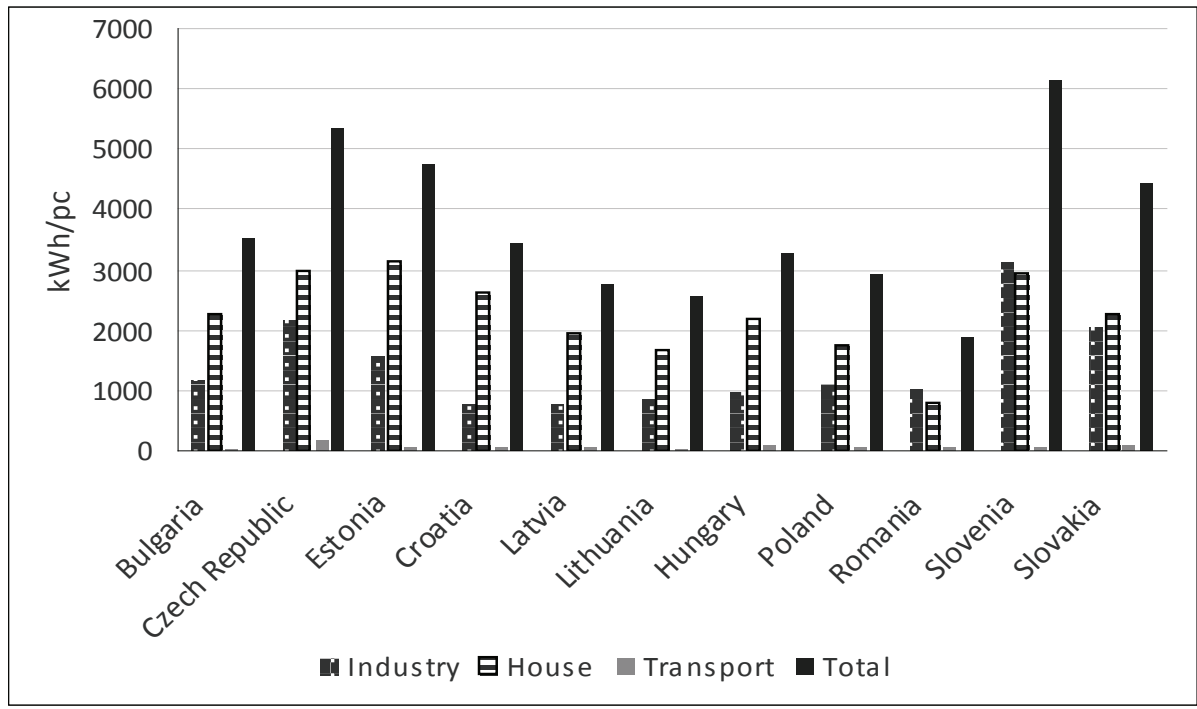

S o u r c e: Eurostat ${ }^{22}$.

The former shows the presence of mild upward trends with possible structural break(s) in most cases, whereas the latter demonstrates the differences present in per capita electricity consumption of post-transition EU countries. The descriptive statistics from Table 1 makes these differences more observable.

TABLE 1: Descriptive statistics for electricity consumers (in $\mathrm{kwh} / \mathrm{pc}$ )

\begin{tabular}{|l|c|c|c|c|c|}
\hline \multicolumn{1}{|c|}{ Sector } & Obs. & Mean & Std.Dev. & $\begin{array}{c}\text { Minimum } \\
\text { (country, year) }\end{array}$ & $\begin{array}{c}\text { Maximum } \\
\text { (country, year) }\end{array}$ \\
\hline Industry & 132 & $1,434.26$ & 730.69 & $\begin{array}{c}657.48 \\
\text { (Latvia, 2002) }\end{array}$ & $\begin{array}{c}3,714.73 \\
\text { (Slovenia, 2007) }\end{array}$ \\
\hline $\begin{array}{l}\text { Households } \\
\text { + services }\end{array}$ & 132 & $2,230.53$ & 695.57 & $\begin{array}{c}490.07 \\
\text { (Romania, 2002) }\end{array}$ & $\begin{array}{c}3,555.64 \\
\text { (Estonia, 2012) }\end{array}$ \\
\hline Transport & 132 & 86.87 & 47.13 & $\begin{array}{c}21.54 \\
\text { (Lithuania, 2007) }\end{array}$ & $\begin{array}{c}223.52 \\
\text { (Czech Rep., 2007) }\end{array}$ \\
\hline Total & 132 & $3,751.65$ & 1263.72 & $\begin{array}{c}1,595.19 \\
\text { (Romania, 2002) }\end{array}$ & $\begin{array}{c}6,597.77 \\
\text { (Slovenia, 2007) }\end{array}$ \\
\hline
\end{tabular}

N o t e: Obs. $=$ observation; Std.Dev. $=$ standard deviation .

\footnotetext{
22 Ibidem.
} 
In post-transition EU countries, household and service per capita electricity consumption makes up on average about $60 \%$ of total per capita electricity consumption, while the share of per capita electricity consumption of the industrial sector makes up on average about $38 \%$. The transport sector has the lowest share of per capita electricity consumption (2.3\%). Such distribution of per capita electricity consumption by sectors is consistent with the $\mathrm{EU}^{23}$, although one should note that old EU Member States have greater total electricity consumption than post-transition EU countries ${ }^{24}$.

Moreover, electricity consumption per unit of gross domestic product (GDP) in post-transition EU countries is above the EU-28 and the EA-19 averages, while most of the old EU Member States are positioned around these averages, indicating the differences in the level of economic development and the large potential for greater energy efficiency in post-transition EU countries. Figure 3 portrays electricity consumption per unit of GDP (using Purchasing Power Standards) in the EU-28. Just for the sake of comparison, the same situation was also recorded in 2002, meaning that the same eight old EU countries (Austria, Germany, Italy, the United Kingdom, the Netherlands, Ireland, Luxembourg and Denmark) were also below the EU-28 and the EA-19 averages.

FIGURE 3: Electricity consumption per unit of GDP in the EU-28 in 2013

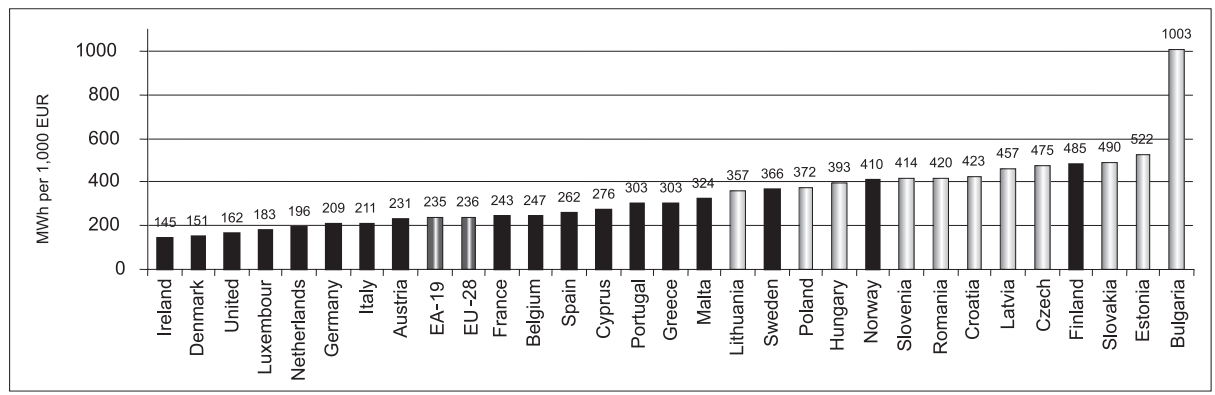

S o u r c e: Eurostat ${ }^{25}$.

Certainly, in contrast to post-transition EU countries, more economically developed EU countries have the economic base using energy efficient technologies, and hence, they accumulated more economic benefits for energy conservation.

23 Ibidem.

24 See also M. Ivanovic, D. Blazevic, H. Glavas, The structure ..., pp. 19-34.

25 Eurostat, Electricity and heat statistics, data from May 2015, http://ec.europa.eu/eurostat/ statistics-explained/index.php/Electricity_and_heat_statistics; retrieved 2.08.2015. 
The data from Table 1 and figures unveil significant differences that exist among post-transition EU countries with respect to their per capita electricity consumption. They indicate that the most developed post-transition EU countries like Slovenia or the Czech Republic are the largest final consumers of electricity, while Romania, which has the lowest per capita GDP, also has the lowest level of per capita electricity consumption.

As suggested by Meng et al. ${ }^{26}$ and Mishra and $\mathrm{Smith}^{27}$, to mitigate the implications of possible cross-sectional shocks, for each country $i$, the natural logarithm of the ratio of per capita electricity consumption (EC) relative to the average of all eleven post-transition EU countries in the sample is given by the expression:

$$
\mathrm{REC}_{\mathrm{it}}=\ln \left(\mathrm{EC}_{\mathrm{it}} / \text { average } \mathrm{EC}_{\mathrm{t}}\right) \text {, }
$$

where $\mathrm{REC}_{\mathrm{it}}$ denotes relative per capita electricity consumption in the country $i$ in the year $t$. Now, the transformed series measure relative per capita electricity consumption.

\subsection{Methodology}

To test for a unit root in the panel dataset, several tests were used. In this paper, the Pesaran cross-section augmented Dickey-Fuller (CADF) and Im, Pesaran and Shin (CIPS) tests are used first. Thereby, the simple CADF regression for the series on the $\mathrm{i}^{\text {th }}$ cross-section unit at time $t\left(\mathrm{y}_{\mathrm{it}}\right)$ is

$$
\Delta \mathrm{y}_{\mathrm{it}}=\mathrm{a}_{\mathrm{i}}+\mathrm{b}_{\mathrm{i}} \mathrm{y}_{\mathrm{it}-1}+\mathrm{c}_{\mathrm{i}} \overline{\mathrm{y}}_{\mathrm{t}-1}+\mathrm{d}_{\mathrm{i}} \Delta \overline{\mathrm{y}}_{\mathrm{t}}+\varepsilon_{\mathrm{it}} \text {, }
$$

where $\bar{y}_{t}$ is the average at time $t$ of all $\mathrm{N}$ observations, $a, b, c$ and $d$ are parameters and $\varepsilon_{\mathrm{it}}$ is the error term. The cross-sectional averages $\overline{\mathrm{y}}_{\mathrm{t}}$ and $\Delta \overline{\mathrm{y}}$ serve as proxies for the effects of an unobserved common factor. The regression must be augmented and lagged, first-differences of both $\mathrm{y}_{\mathrm{it}}$ and $\overline{\mathrm{y}}_{\mathrm{t}}$ must be added if there is serial correlation in the error term or the factor; thus, the $\mathrm{p}^{\text {th }}$ order CADF regression is

$$
\Delta \mathrm{y}_{\mathrm{it}}=\mathrm{a}_{\mathrm{i}}+\mathrm{b}_{\mathrm{i}} \mathrm{y}_{\mathrm{it}-1}+\mathrm{c}_{\mathrm{i}} \overline{\mathrm{y}}_{\mathrm{t}-1}+\sum_{\mathrm{i}=0}^{\mathrm{p}} \mathrm{d}_{\mathrm{ij}} \Delta \overline{\mathrm{y}}_{\mathrm{t}-\mathrm{j}}+\sum_{\mathrm{i}=0}^{\mathrm{p}} \delta_{\mathrm{ij}} \Delta \mathrm{y}_{\mathrm{it}-1}+\varepsilon_{\mathrm{it}} .
$$

26 M. Meng, J.E. Payne, J. Lee, Convergence in per capita energy use among OECD countries, Energy Economics 2013/36: 536-545.

27 V. Mishra, R. Smyth, Convergence in energy consumption per capita among ASEAN countries, Energy Policy 2014/73: 180-185. 
The CIPS statistics is

$$
\mathrm{CIPS}=\frac{1}{\mathrm{~N}} \sum_{\mathrm{i}=1}^{\mathrm{N}} \mathrm{CADF}_{\mathrm{i}}
$$

These tests, explained in detail in Pesaran ${ }^{28}$, allow for potential correlations across residuals of panel units. The CIPS statistic is based on the simple average of the standardized individual CADF $\mathrm{Z}_{\mathrm{t} \text {-bar }}$ statistics of each unit in the panel, while the robust t-bar statistic is obtained by transforming the data (i.e., prewhitening to adjust for short-run serial correlations of the error) before computing regression so that the standard t-bar statistics can be used.

However, the Pesaran tests do not take into account possible structural changes and their potential impacts on the convergence hypothesis. Moreover, they are designed to jointly test the null hypothesis of a unit root for all members of the panel. To mitigate these challenges, the Zivot and Andrews ${ }^{29}$ (hereafter ' ZA') test and the Clemente-Montańés-Reyes ${ }^{30}$ (hereafter 'CMR') test allowing for structural breaks(s) in each panel members are also used in this paper.

The ZA test has a null hypothesis that the given series contains a unit root with drift that excludes any structural break (equation 4). The alternative hypothesis is the presence of a one-time structural break in the level and the slope of the trend function of the series occurring at an unknown point in time (equation 5). It refers to the so-called model $\mathrm{C}$ since $\mathrm{Sen}^{31}$ shows that model $\mathrm{C}$ is most superior of the three variants (model A, B and C) developed by ZA.

$$
\begin{gathered}
\mathrm{H}_{0}: \mathrm{y}_{\mathrm{t}}=\mu+\mathrm{y}_{\mathrm{t}-1}+\mathrm{e}_{\mathrm{t}} \\
\mathrm{H}_{1}: \mathrm{y}_{\mathrm{t}}=\mu+\theta \mathrm{DU}_{\mathrm{t}}(\lambda)+\beta \mathrm{t}+\gamma \mathrm{DT}_{\mathrm{t}}(\lambda)+\alpha \mathrm{y}_{\mathrm{t}-1}+\sum_{\mathrm{j}=1}^{\mathrm{k}} \mathrm{c}_{\mathrm{j}} \Delta \mathrm{y}_{\mathrm{t}-\mathrm{j}}+\mathrm{e}_{\mathrm{t}},
\end{gathered}
$$

where $\mathrm{DU}_{t}$ and $\mathrm{DT}_{t}$ denote dummy variables. The former captures a shift in the intercept (mean), while the latter represents a break in the trend occurring

28 M.H. Pesaran, A simple unit root test in the presence of cross-section dependence, Journal of Applied Econometrics 2007/22: 265-312.

29 E. Zivot, D.W.K. Andrews, Further evidence on the Great Crash, the oil price shock, and the Unit-Root Hypothesis, Journal of Business and Economic Statistics 1992/10: 251-270.

30 J. Clemente, A. Montañes, M. Reyes, Testing for a unit root in variables with a double change in the mean, Economics Letters 1998/59 (2): 175-182.

31 A. Sen, On unit root tests when the alternative is a trend break stationary process, Journal of Business and Economic Statistics 2013/21: 174-184. 
at a break time (TB). $\lambda$ represents the break fraction which is estimated by minimizing t-statistics for $\alpha=1 . \mu, \theta, \beta, \gamma$ and $\alpha$ are parameters, while $\mathrm{k}$ is the number of extra regressors determined by a test of significance of the estimated coefficients $c_{i}$. For $\mathrm{DU}_{\mathrm{t}}$ and $\mathrm{DT}_{\mathrm{t}}$ holds: $\mathrm{DU}_{\mathrm{t}}(\lambda)=1$ if $\mathrm{t}>\mathrm{TB}$, zero otherwise; $\operatorname{DT}_{t}(\lambda)=t-T \lambda$ if $t>T B$, zero otherwise.

The CMR test relaxes the assumption about only one structural break and allows for two breaks in the mean of the series. It has a null hypothesis that the given series is a unit root with two structural breaks (equation 6), while the alternative one is the presence of a stationary series with two structural breaks (equation 7).

$$
\begin{gathered}
\mathrm{H}_{0}: \mathrm{y}_{\mathrm{t}}=\mathrm{y}_{\mathrm{t}-1}+\delta_{1} \mathrm{DTB}_{1 \mathrm{t}}+\delta_{2} \mathrm{DTB}_{2 \mathrm{t}}+\mu_{\mathrm{t}} \\
\mathrm{H}_{1}: \mathrm{y}_{\mathrm{t}}=\mu+\mathrm{d}_{1} \mathrm{DU}_{1 \mathrm{t}}+\mathrm{d}_{2} \mathrm{DTB}_{2 \mathrm{t}}+\mathrm{e}_{\mathrm{t}},
\end{gathered}
$$

where $\mathrm{DTB}_{\mathrm{it}}$ is a dummy variable with the value 1 if $\mathrm{t}=\mathrm{TB}_{\mathrm{i}}+1(\mathrm{i}=1,2)$ and zero otherwise, and $\mathrm{DU}_{\mathrm{it}}=1$ if $\mathrm{t}>\mathrm{TB}_{\mathrm{i}}(\mathrm{i}=1,2)$ and zero otherwise. $\mathrm{TB}_{1}$ and $\mathrm{TB}_{2}$ are the time periods when the mean is being identified. CMR stress that $\mathrm{TB}_{\mathrm{i}}=\lambda_{\mathrm{i}} \mathrm{T}$ $(\mathrm{i}=1,2)$ with $0<\lambda_{\mathrm{i}}<1$, and also that $\lambda_{2}>\lambda_{1}$ can be supposed for the sake of simplicity.

CMR developed two variants of the model: an additive outliers (AO) model, which captures a sudden change in the mean of the series, and an innovational outliers (IO) model, which allows for a gradual shift in the mean of the series. In this paper, both models are used.

\section{Results and discussion}

Since the Pesaran test is sensitive to the choice of the appropriate lag order, the Akaike information criterion (up to 3 lags) was used to select the appropriate lag order for the CADF regressions underlying the CIPS tests. Afterwards the CIPS tests based on CADF-regressions with the respective previously determined lag-lengths were applied. Table 2 presents the results for the standardized $\mathrm{Z}_{\mathrm{t} \text {-bar }}$ statistic and its $p$-value as well as t-bar statistics for each panel series. 
TABLE 2: Results of the Pesaran test

\begin{tabular}{|l|c|r|r|r|r|}
\hline & Lag & 0 & 1 & \multicolumn{1}{c|}{2} & 3 \\
\hline \multirow{4}{*}{ REC $_{\text {industry }}$} & $\mathrm{Z}_{\text {t-bar }}$ & $-0,107$ & 0,277 & 11,832 & 11,832 \\
\cline { 2 - 6 } & $\mathrm{p}$-value & 0,457 & 0,609 & 1,000 & 1 \\
\cline { 2 - 6 } & $\mathrm{t}$-bar & $-2,296$ & $-2,167$ & 1,700 & 1,700 \\
\hline \multirow{2}{*}{ REC $_{\text {households \& }}$} & $\mathrm{Z}_{\mathrm{t} \text {-bar }}$ & $-0,943$ & $-0,184$ & 11,832 & 16,203 \\
\cline { 2 - 6 } & $\mathrm{p}$-value & 0,173 & 0,427 & 1,000 & 1 \\
\cline { 2 - 6 } & $\mathrm{t}$-bar & $-2,576$ & $-2,322$ & 1,700 & 1,700 \\
\hline \multirow{3}{*}{ REC $_{\text {transport }}$} & $\mathrm{Z}_{\text {t-bar }}$ & 1,028 & 1,156 & 11,832 & 11,832 \\
\cline { 2 - 6 } & $\mathrm{p}$-value & 0,848 & 0,876 & 1,000 & 1 \\
\cline { 2 - 6 } & $\mathrm{t}$-bar & $-1,916$ & $-1,873$ & 1,700 & 1,700 \\
\hline \multirow{3}{*}{ REC $_{\text {total }}$} & $\mathrm{Z}_{\mathrm{t} \text {-bar }}$ & 1,141 & 0,906 & 11,832 & 11,832 \\
\cline { 2 - 6 } & $\mathrm{p}$-value & 0,873 & 0,817 & 1,000 & 1,000 \\
\cline { 2 - 6 } & $\mathrm{t}$-bar & $-1,878$ & $-1,957$ & 1,700 & 1,700 \\
\hline
\end{tabular}

Note: The Stata routines pescadf written by $\mathrm{P}$. Lewandowski ${ }^{32}$ and $x$ tcips written by M. Sangiacomo ${ }^{33}$ were used to obtain estimation of the $Z_{t \text {-bar }}$ and CIPS statistics, respectively. Deterministics chosen: constant and trend. Critical values for the CIPS statistics at the $1 \%, 5 \%$ and $10 \%$ significance level are $-3.070,-2.820,-2.680$, respectively.

The results reveal that the null hypothesis of a unit root should not be rejected for each panel as a whole at the 5 percent level. This implies at least four important policy implications. First, any significant shock to per capita electricity consumption, regardless of which sector it is about, is likely to have a permanent effect on eleven post-transition EU countries. Hence, their future behavior will become path-dependent. Second, the impacts generated by the shock(s) may be transmitted to other macroeconomic variables, as suggested by Hendry and Juselius ${ }^{34}$, which may be unfavorable and undesirable in the case of adverse shock(s). Third, the past development of electricity consumption cannot be used to forecast electricity consumption and energy demand, which adds an additional uncertainty to managing electricity consumption. Fourth, new policy efforts are needed to develop a single electricity market.

32 P. Lewandowski, PESCADF: Stata module to perform Pesaran's CADF panel unit root test in presence of cross section dependence', Statistical Software Component No. S456732, Boston College Department of Economics, Boston 2007.

33 M. Sangiacomo, XTCIPS: Stata module to compute Pesaran panel unit root test in the presence of cross-section dependence, Boston College, Department of Economics. Statistical Software Components S444302; revised 17.06.2005, Boston 2014.

34 D.F. Hendry, K. Juselius, Explaining..., pp. 1-42. 
However, the findings may become vague if a structural break is statistically significant. Additionally, as suggested by Das et al..$^{35}$, the application of panel unit root tests may not provide sufficient evidence to conclude that all series in the panels have a unit root, or that they are all stationary. To take into account possible structural breaks in individual time-series within the panel, the following two panel unit root tests with structural breaks were employed in this paper: the ZA panel unit root test and the CMR panel unit-root test with double mean shifts, the AO model and the IO model.

The ZA test was used to test for a unit root allowing for one endogenously determined structural break. The relative per capita electricity consumption series over the period 2002-2013 were estimated. Table 3 shows the results of these tests.

TABLE 3: Results of the ZA test

\begin{tabular}{|l|c|c|c|c|c|c|c|c|}
\hline \multirow{2}{*}{ Country } & \multicolumn{2}{|c|}{$\mathrm{REC}_{\text {industry }}$} & \multicolumn{2}{c|}{$\mathrm{REC}_{\text {households \& services }}$} & \multicolumn{2}{c|}{$\mathrm{REC}_{\text {transport }}$} & \multicolumn{2}{c|}{$\mathrm{REC}_{\text {total }}$} \\
\cline { 2 - 9 } & $\mathrm{TB}$ & $\mathrm{t}$-test & $\mathrm{TB}$ & $\mathrm{t}$-test & $\mathrm{TB}$ & $\mathrm{t}$-test & $\mathrm{TB}$ & $\mathrm{t}$-test \\
\hline Bulgaria & 2009 & $-6.035^{*}$ & 2011 & -2.399 & 2009 & -3.967 & 2009 & $-7.297^{*}$ \\
\hline Czech R. & 2009 & -4.213 & 2006 & -4.045 & 2008 & -4.562 & 2006 & $-7.484^{*}$ \\
\hline Estonia & 2009 & $-6.781^{*}$ & 2009 & -4.406 & 2009 & -3.736 & 2010 & -1.651 \\
\hline Croatia & 2009 & $-5.360^{* *}$ & 2008 & -3.334 & 2009 & -2.775 & 2009 & -4.550 \\
\hline Latvia & 2005 & -2.721 & 2009 & -4.091 & 2009 & -3.530 & 2009 & -3.789 \\
\hline Lithuania & 2011 & -4.257 & 2009 & -3.118 & 2007 & $-9.454 *$ & 2009 & -3.640 \\
\hline Hungary & 2010 & -4.184 & 2011 & 1.399 & 2008 & $-6.496 *$ & 2007 & -1.842 \\
\hline Poland & 2009 & $-5.812^{*}$ & 2011 & -1.810 & 2006 & $-4.957 * * *$ & 2009 & -4.271 \\
\hline Romania & 2009 & -4.329 & 2011 & -4.383 & 2008 & -2.692 & 2009 & $-4.857 * * *$ \\
\hline Slovenia & 2009 & -2.968 & 2008 & $-10.677 *$ & 2009 & $-5.719 *$ & 2009 & $-5.719 * *$ \\
\hline Slovakia & 2009 & $-8.995 *$ & 2007 & -3.951 & 2009 & -3.877 & 2009 & -3.877 \\
\hline
\end{tabular}

$\mathrm{N}$ o t e: $\mathrm{TB}=$ break point. *denotes statistical significance at the $5 \%$ level. The critical value is -4.42 at this significance level. The Stata routine zandrews (implemented by C.F. Baum ${ }^{36}$ ) was used to obtain estimates of t-statistics. The optimal lag length was selected via a TT test.

35 S. Das, R. Gupta, P.A. Kaya, Convergence of metropolitan house prices in South Africa: A Reexamination using efficient unit root tests, Applied Econometrics and International Development 2010/10 (1): 173-188.

36 C.F. Baum, ZANDREWS: Stata module to calculate Zivot-Andrews unit root test in presence of structural break, Boston College, Department of Economics. Statistical Software Components S437301 (revised 29.11.2009), Boston 2004. 
The results point out that none of the variables of interest is fully integrated across all series, i.e., that besides non-stationary processes, each of them includes at least one trend-stationary process. This means that shocks are likely to have a permanent effect on electricity consumption sectors in the majority of countries, while for only several ones they will probably not permanently change the growth path of the variables. Hence, the ZA tests indicate that disaggregated electricity consumption variables react differently to structural break(s). The null hypothesis is rejected for industry in five cases (for Bulgaria, Estonia, Croatia, Poland and Slovakia), for households and service in only one case (Slovenia), for transport in three cases (Lithuania, Poland and Slovenia), and for total electricity consumption in four cases (Bulgaria, the Czech Republic, Romania and Slovenia) out of eleven post-transition EU countries. According to the ZA tests, the shock mostly refers to the years marked by the financial and economic crisis. This is expected, bearing in mind Figure 1 and the recent situation in the EU. Namely, a severe economic situation dampens the rate of electricity demand growth. For example, statistical data in the EU show that final electricity consumption decreased by $5.2 \%$ in 2009 , but recovered immediately in 2010 almost back to the 2008 level ${ }^{37}$.

However, the results of the ZA tests may be called into question if actually more than one break exists (Ben-David et al. ${ }^{38}$ ). To test for a unit root in the presence of double structural breaks, the CMR unit-root test with double mean shifts was also employed.

The results for the AO model and the IO model, which allows for two breaks in both the slope and the intercept, are reported in Table 4 (from Table 4A to Table 4D).

TABLE 4: Results of the CMR test for the IO and the AO model

TABLE 4A: Industrial sector

\begin{tabular}{|l|c|c|c|c|c|c|c|}
\hline \multirow{3}{*}{ Country } & \multicolumn{9}{|c|}{ REC $_{\text {industry }}$} \\
\cline { 2 - 8 } & \multirow{2}{*}{$l$} & \multicolumn{3}{|c|}{ IO model } & \multicolumn{3}{c|}{ AO model } \\
\cline { 3 - 8 } & & t-stat & TB1 & TB2 & t-stat & TB1 & TB2 \\
\hline Bulgaria & 2 & -5.14 & 2004 & 2007 & $-14.372 *$ & 2005 & 2008 \\
\hline Czech & 2 & -1.284 & 2008 & 2010 & -2.51 & 2005 & 2008 \\
\hline Estonia & 1 & -3.462 & 2005 & 2007 & -3.038 & 2005 & 2009 \\
\hline Croatia & 1 & -2.577 & 2004 & 2009 & -3.513 & 2005 & 2010 \\
\hline
\end{tabular}

37 See Eurostat, Electricity and heat statistics, data from May 2015, http://ec.europa.eu/eurostat/ statistics-explained/index.php/Electricity_and_heat_statistics; retrieved 2.08.2015.

38 D. Ben-David, R. Lumsdaine, D.H. Papell, Unit root, postwar slowdowns and long-run growth: Evidence from two structural breaks, Empirical Economics 2013/28: 303-319. 


\begin{tabular}{|l|c|c|c|c|c|c|c|}
\hline \multirow{2}{*}{ Country } & \multicolumn{6}{|c|}{ REC $_{\text {industry }}$} \\
\cline { 2 - 8 } & \multirow{2}{*}{} & $l$ & \multicolumn{3}{|c|}{ IO model } & \multicolumn{3}{c|}{ AO model } \\
\cline { 2 - 8 } & & t-stat & TB1 & TB2 & t-stat & TB1 & TB2 \\
\hline Latvia & 1 & -1.772 & 2004 & 2011 & -1.878 & 2005 & 2009 \\
\hline Lithuania & 1 & -1.669 & 2005 & 2010 & -5.085 & 2005 & 2009 \\
\hline Hungary & 2 & -2.938 & 2007 & 2010 & $-7.036^{*}$ & 2006 & 2009 \\
\hline Poland & 1 & -1.986 & 2005 & 2010 & $-5.502^{*}$ & 2003 & 2012 \\
\hline Romania & 1 & -4.082 & 2007 & 2011 & $-6.07^{*}$ & 2003 & 2006 \\
\hline Slovenia & 1 & $-8.489 *$ & 2004 & 2007 & -2.276 & 2005 & 2009 \\
\hline Slovakia & 1 & -3.615 & 2004 & 2007 & -3.165 & 2005 & 2009 \\
\hline
\end{tabular}

TABLE 4B: Household and service sector

\begin{tabular}{|l|c|c|c|c|c|c|c|}
\hline \multirow{2}{*}{ Country } & \multicolumn{7}{|c|}{ REC $_{\text {households \& services }}$} \\
\cline { 2 - 8 } & \multirow{2}{*}{$l$} & \multicolumn{3}{|c|}{ IO model } & \multicolumn{3}{c|}{ AO model } \\
\cline { 3 - 8 } & & t-stat & TB1 & TB2 & t-stat & TB1 & TB2 \\
\hline Bulgaria & 1 & -1.606 & 2004 & 2012 & -2.383 & 2007 & 2011 \\
\hline Czech & 1 & $-7.941^{*}$ & 2004 & 2011 & $-7.215^{*}$ & 2003 & 2006 \\
\hline Estonia & 1 & -2.509 & 2004 & 2006 & -3.563 & 2005 & 2007 \\
\hline Croatia & 1 & -0.571 & 2007 & 2009 & $-7.750^{*}$ & 2005 & 2007 \\
\hline Latvia & 1 & -3.661 & 2004 & 2011 & -2.764 & 2009 & 2011 \\
\hline Lithuania & 1 & -1.736 & 2004 & 2006 & -3.386 & 2005 & 2008 \\
\hline Hungary & 1 & 0.236 & 2004 & 2006 & -1.587 & 2005 & 2008 \\
\hline Poland & 1 & -4.317 & 2004 & 2010 & -2.917 & 2003 & 2007 \\
\hline Romania & 1 & -2.873 & 2004 & 2009 & -4.242 & 2006 & 2009 \\
\hline Slovenia & 2 & $-13.537 *$ & 2006 & 2010 & -5.377 & 2005 & 2008 \\
\hline Slovakia & 1 & -4.466 & 2003 & 2008 & -4.141 & 2005 & 2008 \\
\hline
\end{tabular}

TABLE 4C: Transport sector

\begin{tabular}{|l|c|c|c|c|c|c|c|}
\hline \multirow{3}{*}{ Country } & \multicolumn{6}{|c|}{ REC $_{\text {transport }}$} \\
\cline { 2 - 8 } & \multirow{2}{*}{} & $l$ & \multicolumn{3}{|c|}{ IO model } & \multicolumn{3}{c|}{ AO model } \\
\cline { 3 - 8 } & & t-stat & TB1 & TB2 & t-stat & TB1 & TB2 \\
\hline Bulgaria & 1 & -2.715 & 2006 & 2010 & $-11.27^{*}$ & 2007 & 2011 \\
\hline Czech & 1 & $-9.081^{*}$ & 2006 & 2011 & -5.335 & 2005 & 2009 \\
\hline Estonia & 1 & -0.432 & 2004 & 2006 & -2.524 & 2003 & 2008 \\
\hline
\end{tabular}




\begin{tabular}{|l|c|c|c|c|c|c|c|}
\hline \multirow{2}{*}{ Country } & \multicolumn{6}{|c|}{ REC $_{\text {transport }}$} \\
\cline { 2 - 8 } & \multirow{2}{*}{$l$} & \multicolumn{3}{|c|}{ IO model } & \multicolumn{3}{c|}{ AO model } \\
\cline { 3 - 8 } & & t-stat & TB1 & TB2 & t-stat & TB1 & TB2 \\
\hline Croatia & 1 & -3.818 & 2003 & 2010 & -3.157 & 2005 & 2009 \\
\hline Latvia & 1 & -1.720 & 2008 & 2010 & -1.613 & 2008 & 2011 \\
\hline Lithuania & 1 & $-15.93^{*}$ & 2003 & 2005 & -3.416 & 2006 & 2008 \\
\hline Hungary & 1 & -2.054 & 2004 & 2011 & -4.587 & 2005 & 2009 \\
\hline Poland & 1 & -3.875 & 2004 & 2007 & $-9.064 *$ & 2005 & 2008 \\
\hline Romania & 1 & -3.573 & 2004 & 2011 & -4.347 & 2003 & 2011 \\
\hline Slovenia & 2 & -4.726 & 2007 & 2011 & -3.202 & 2008 & 2012 \\
\hline Slovakia & 1 & -5.007 & 2003 & 2007 & -2.315 & 2006 & 2009 \\
\hline
\end{tabular}

TABLE 4D: Total consumption

\begin{tabular}{|l|c|c|c|c|c|c|c|}
\hline \multirow{2}{*}{ Country } & \multicolumn{9}{|c|}{ REC $_{\text {total }}$} \\
\cline { 2 - 8 } & \multirow{2}{*}{$l$} & \multicolumn{3}{|c|}{ IO model } & \multicolumn{3}{c|}{ AO model } \\
\cline { 3 - 8 } Bulgaria & 1 & $-8.168^{*}$ & 2005 & 2008 & -2.637 & 2007 & 2011 \\
\hline Czech & 1 & $-10.37^{*}$ & 2007 & 2011 & $-7.26^{*}$ & 2007 & 2010 \\
\hline Estonia & 1 & -2.480 & 2003 & 2009 & -1.016 & 2006 & 2008 \\
\hline Croatia & 1 & -3.103 & 2004 & 2011 & -3.537 & 2005 & 2011 \\
\hline Latvia & 1 & $-5.55^{*}$ & 2007 & 2011 & -3.335 & 2006 & 2009 \\
\hline Lithuania & 1 & $-6.739 *$ & 2004 & 2008 & -3.272 & 2005 & 2009 \\
\hline Hungary & 1 & -0.616 & 2004 & 2006 & -2.753 & 2005 & 2008 \\
\hline Poland & 1 & -2.515 & 2005 & 2009 & -4.280 & 2005 & 2010 \\
\hline Romania & 1 & -3.152 & 2004 & 2007 & -1.261 & 2003 & 2008 \\
\hline Slovenia & 2 & -4.726 & 2007 & 2011 & -3.202 & 2008 & 2012 \\
\hline Slovakia & 1 & -5.007 & 2003 & 2007 & -2.315 & 2006 & 2009 \\
\hline
\end{tabular}

N o t e: *denotes statistical significance at the $5 \%$ level. The critical value at this significance level is -5.490 . Lag length $l$ was chosen due to the minimum of the modified AIC. The Stata routine clemao2 and clemio2 (implemented by C.F. Baum ${ }^{39}$ ) was used to obtain estimates statistics.

39 C.F. Baum, CLEMAO_IO: Stata module to perform unit root tests with one or two structural breaks, Boston College, Department of Economics. Statistical Software Components S444302 (revised 17.06.2005), Boston 2005. 
The results support the stationarity or convergence hypothesis with two structural breaks for only several cases (i.e., countries). Thereby, in most cases, industry is exposed to sudden changes (4 out of 11), while other consumer sectors (households with services and transport) are exposed to gradual changes ( 2 each out of 11). The time break years for the AO and the IO model suggest that electricity consumption reacts not only to the financial and economic crises but also to other economic and non-economic innovations such as, for example, weather condition, electricity or fuel price changes or legislative and regulation changes. Some of these innovations are case-, i.e., country-specific.

Comparing the results with no-break, one break or two breaks, Madsen et al. ${ }^{40}$ stress that as a rule of thumb, the one-break case should be preferred to the nobreak case if the break is statistically significant and the two-break case should be preferred if the second break is statistically significant. Hence, the panel unit root tests with structural break(s) detect that each country under investigation faced significant structural break(s) affecting at least one of its electricity consumption sectors. Thereby, it seems that the breaks are not temporary phenomena that will disappear in the future for the majority of countries.

Finding evidence of a unit root in the majority of countries in the sample is in line with those of Zachmann ${ }^{41}$ or Pellini ${ }^{42}$, who conclude that the efforts to develop a single European electricity market were so far only partially successful.

\section{Conclusion}

The question of whether electricity consumption is a stationary or a non-stationary process is of great policy interest. Namely, if it is a non-stationary process, then the shocks affecting it are likely to have a permanent effect, and its past behavior will not be useful for forecasting future electricity demand. For example, in the case of an adverse shock, it could be transmitted to other important macroeconomic variables, and contribute to unfavorable movements in an economy. Additionally,

40 J.B. Madsen, V. Mishra, R. Smyth, Is the output-capital ratio constant in the very long time?, The Manchester School 2012/80 (2): 210-236.

41 G. Zachman, Electricity wholesale market prices in Europe: Convergence?, Energy Economics 2008/30 (4): 1659-1671.

42 E. Pellini, Convergence across EU electricity wholesale spot markets: Still a way to go, in: Proceedings of the $12^{\text {th }}$ IAEE European Energy Conference, Venice, 1-36, 2012, https://editorialexpress.com/cgi-bin/conference/download.cgi?db_name=res_phd_2013\&paper_id=274; retrieved 20.10.2015. 
when electricity consumption is a unit root process, it may deviate from the trend because of a shock. In that case, government should formulate and implement specific electricity programs and measures to reach the policy targets. On the other hand, if electricity consumption is a stationary process, then the shocks are likely to have a temporary effect, and its future development will return to its long-run trend path. Hence, it can be used for forecasting.

This paper examined the time-series properties of relative per capita electricity consumption disaggregated by consumer sectors for eleven post-transition EU countries in the period 2002-2013. To that end, it applied the panel unit root tests without (the Pesaran test) and with structural break(s) (the ZA and the CMR tests). The results of the former indicated that the panel as a whole is a nonstationary process regardless of which electricity consumption series, i.e., sector (industry, households and services or transport), was investigated. The results of the latter indicated that each country was faced with at least one structural shock affecting at least one of its electricity consumption sectors. Moreover, they reveal that each sector reacts differently to shock(s). Thereby, relative per capita electricity consumption by industry was exposed more frequently to shocks and also to sudden changes, whereas households, services and transport were similarly exposed to gradual and sudden changes.

However, considering simultaneously the time-series properties of each electricity consumption series by sector and country, one should observe that they are unit root processes in the majority of the countries in the sample. This evidence is not consistent with the EU objective of creating an integrated electricity market. Furthermore, the results also suggest that EU and national energy policies have to address the fact that electricity consumption sectors react differently to energy and non-energy shocks. Moreover, when electricity consumption is a unit root process deviating from the trend because of the shock, then the government should formulate and implement specific energy programs and measures to reach the policy targets. Although electricity consumption follows a stochastic trend (i.e., is a unit root process) in the most post-transition EU economies, as the results suggest, a country-specific approach is needed for understanding the electricity consumption behavior of the sample as a whole and also for formulating energy policy programs and measures aiming at improving energy efficiency and achieving the EU energy objectives. 


\section{References}

Aslan Alper, Does natural gas consumption follow a nonlinear path over time? Evidence from 50 states, Renewable and Sustainable Energy Reviews 2011/15: 4466-4469.

Aslan Alper, Kum Hakan, The stationarity of energy consumption for Turkish disaggregate data by employing linear and nonlinear unit root tests, Energy 2011/36: 4256-4258.

Baum Christopher F., ZANDREWS: Stata module to calculate Zivot-Andrews unit root test in presence of structural break, Boston College, Department of Economics. Statistical Software Components S437301 (revised 29.11.2009), Boston 2004.

Baum Christopher F., CLEMAO_IO: Stata module to perform unit root tests with one or two structural breaks, Boston College, Department of Economics. Statistical Software Components S444302 (revised 17.06.2005), Boston 2005.

Ben-David Dan, Lumsdaine Robin L., Papell David H., Unit root, postwar slowdowns and longrun growth: Evidence from two structural breaks, Empirical Economics 2013/28: 303-319.

Buchan David, Refuelling Europe: A roadmap for completing the Single energy market, Wilfried Martens Centre for European Studies, Brussels 2014.

Clemente Jesús, Montañes Antonio, Reyes Marcelo, Testing for a unit root in variables with a double change in the mean, Economics Letters 1998/59 (2): 175-182.

Das Sonali, Gupta Rangan, Kaya Patrick A., Convergence of metropolitan house prices in South Africa: A Reexamination using efficient unit root tests, Applied Econometrics and International Development 2010/10 (1): 173-188.

Eurostat (2015), Electricity and heat statistics, data from May 2015, http://ec.europa.eu/eurostat/ statistics-explained/index.php/Electricity_and heat_statistics; retrieved 2.08.2015.

Hajko Vladimir, Changes in the energy consumption in EU-27 countries, Review of Economic Perspectives 2012/1: 3-21.

Hendry David F., Juselius Katarina, Explaining cointegration analysis: part 1, Energy Journal 2000/21: 1-42.

Hsu Yi-Chung, Lee Chien-Chiang, Lee Chi-Chuan, Revisited: Are shocks to energy consumption permanent or temporary? New evidence from a panel SURADF approach, Energy Economics 2008/30: 2314-2330.

Ivanovic Milan, Blazevic Damir, Glavas Hrvoje, The structure of electricity consumption and its utilization efficiency in the European transition countries, International Journal of Electrical and Computer Engineering Systems 2010/1 (2): 19-34.

Kum Hakan, Are fluctuations in energy consumption transitory or permanent? Evidence from a panel of East Asia \& Pacific countries, International Journal of Energy Economics and Policy 2012/2 (3): 92-96.

Le Pen, Yannick, Sevi Benoit, On the non-convergence of energy intensities: Evidence from a pair-wise econometric approach, Ecological Economics 2010/69 (3): 641-650.

Lewandowski Piotr, PESCADF: Stata module to perform Pesaran's CADF panel unit root test in presence of cross section dependence', Statistical Software Component No. S456732, Boston College Department of Economics, Boston 2007.

Madsen Jacob, Mishra Vinod, Smyth Russell, Is the output-capital ratio constant in the very long time?, The Manchester School 2012/80 (2): 210-236.

Markandya Anil, Pedroso Suzette, Streimikiene Dalia, Energy efficiency in transition economies: Is there convergence towards the EU average?, Energy Economics 2004/28 (1): 121-145. 
Meng Ming, Payne James E., Lee Junsoo, Convergence in per capita energy use among OECD countries, Energy Economics 2013/36: 536-545.

Mishra Vinod, Sharma Susan, Smyth Russell, Are fluctuations in energy consumption per capita transitory? Evidence from a panel of Pacific Island countries, Energy Policy 2009/37: $2318-2326$.

Mishra Vinod, Smyth Russell, Convergence in energy consumption per capita among ASEAN countries, Energy Policy 2014/73: 180-185.

Narayan Paresh K., Smyth Russell, Are shocks to energy consumption permanent or temporary? Evidence from 182 countries, Energy Policy 2007/35: 333-341.

Narayan Paresh K., Narayan Seema, Popp Stephan, Energy consumption at the state level: the unit root null hypothesis from Australia, Applied Energy 2010/87: 1953-1962.

Ortiz Ramon A., Bastianin Andrea, Bigano Andrea, Cattaneo Cristina, Lanza Alessandro, Manera Matteo, Markandya Anil, Plotegher Michele, Sferra Fabio, Energy efficiency in Europe: Trends, convergence and policy effectiveness, MPRA Paper No. 15763, Munich 2009.

Pellini Elisabetta, Convergence across EU electricity wholesale spot markets: Still a way to go, in: Proceedings of the $12^{\text {th }}$ IAEE European Energy Conference, Venice, 1-36, 2012, https:// editorialexpress.com/cgi-bin/conference/download.cgi?db_name=res_phd_2013\&paper $\mathrm{id}=274$; retrieved 20.10.2015.

Pesaran Hashem M., A simple unit root test in the presence of cross-section dependence, Journal of Applied Econometrics 2007/22: 265-312.

Pollitt Michael, Evaluating the evidence on electricity reform: Lessons for the South East Europe (SEE) market, Utilities Policy 2009/17 (1): 13-23.

Robinson Terry, The Convergence of Electricity Prices in Europe, Applied Economics Letters 2007/14: 473-476.

Sangiacomo Maximo, XTCIPS: Stata module to compute Pesaran panel unit root test in the presence of cross-section dependence, Boston College, Department of Economics. Statistical Software Components S444302 (revised 17.06.2005), Boston 2014.

Sen Amit, On unit root tests when the alternative is a trend break stationary process, Journal of Business and Economic Statistics 2013/21: 174-184.

Shahbaz Muhammad, Tiwari Aviral K., Ozturk Ilhan, Farooq Abdul, Are fluctuations in electricity consumption per capita transitory? Evidence from developed and developing economies, Renewable and Sustainable Energy Reviews 2013/28: 551-554.

Smyth Russell, Are fluctuations in energy variables permanent or transitory? A survey of the literature on the integration properties of energy consumption and production, Applied Energy 2013/104: 371-378.

Teixeira Cesar, Albano Michele, Skou Arne, Perez Duenas Lara, Antonacci Francesco, Ferreira Rodrigo, Lotzfeldt Pedersen K., Scalari Sandra, Convergence to the European energy policy in European countries: Case studies and comparison, Social Technologies 2014/4 (1): 7-24.

Zachman Georg, Electricity wholesale market prices in Europe: Convergence?, Energy Economics 2008/30 (4): 1659-1671.

Zivot Eric, Andrews Donald W.K., Further evidence on the Great Crash, the oil price shock, and the Unit-Root Hypothesis, Journal of Business and Economic Statistics 1992/10: 251-270. 
Đula BOROZAN

\section{EFEKTY CZASOWE SZOKÓW NA RYNKU ENERGII ELEKTRYCZNEJ: BADANIA KRAJÓW UE, KTÓRE PRZESZŁY TRANSFORMACJĘ USTROJOWA}

(Streszczenie)

Artykuł opisuje własności szeregów czasowych dla danych dotyczących zużycia energii w podziale według sektorów konsumenckich. Stanowi próbę wykrycia obecności pierwiastka jednostkowego w jedenastu krajach UE, które przeszły transformację ustrojową. W tym celu wykorzystano panelowe testy pierwiastka jednostkowego zawierające strukturalną przerwę oraz testy bez strukturalnej przerwy w szeregu czasowym obejmującym okres 2002-2013.

Wyniki pierwszego rodzaju testów wskazują, że zużycie energii jest procesem pierwiastka jednostkowego w każdym sektorze, co dowodzi, że każdy szok może okazać się trwały. Wyniki testów drugiego rodzaju potwierdzają zerową hipotezę niestacjonarności dla większości badanych krajów i sektorów, a także wskazują, że każdy kraj był narażony na co najmniej jeden istotny szok oddziałujący na zmienne związane z zużyciem energii. Tym samym szoki będą miały w tych przypadkach prawdopodobnie efekty trwałe, a zużycie energii będzie zależne od wcześniejszych uwarunkowań (path-dependent). W związku z tym, w krajach UE, które przeszły transformację ustrojową, niewiele wskazuje na konwergencję w stronę wspólnego rynku energii elektrycznej.

Słowa kluczowe: stacjonarność; panelowe testy pierwiastka jednostkowego; szok; posttransformacyjne kraje UE 